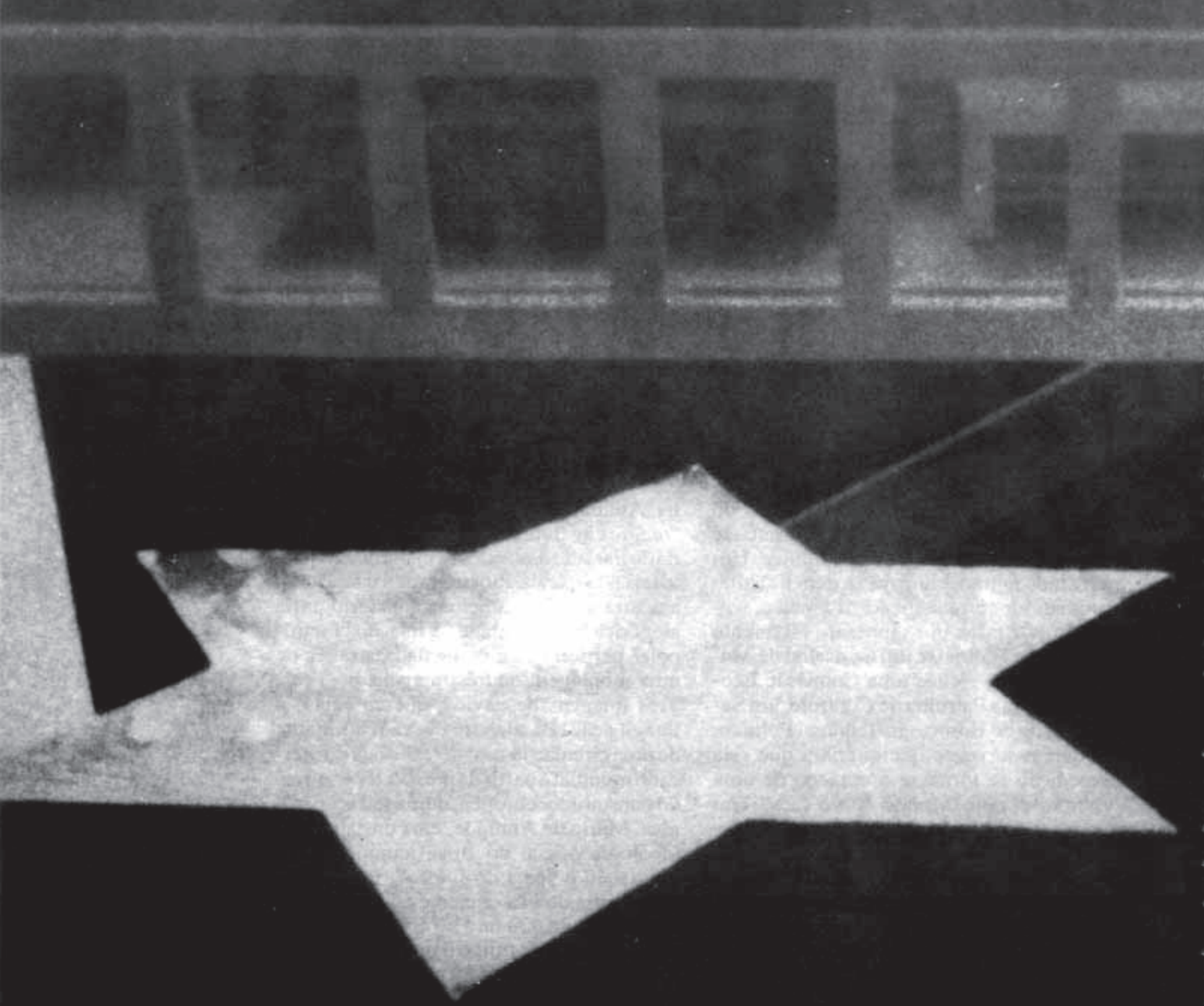




\section{É preciso teologia para pensar o fim da História?}

FILOSOFIA DA HISTÓRIA EM WALTER BENJAMIN

IEANDRO KONDER
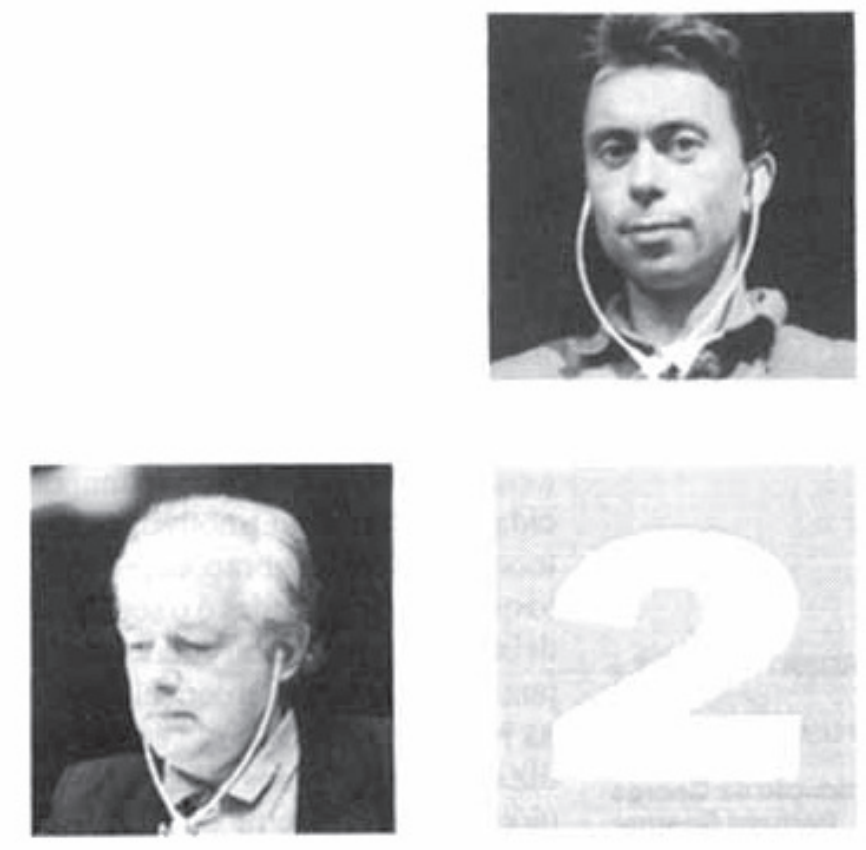


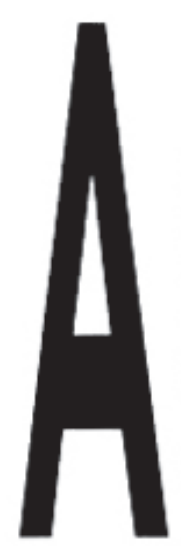

\section{NORBERT W. BOLZ}

ntes de passar a desenvolver $o$ que quero chamar de "lógica benjaminiana do conhecimento histórico", gostaria de situar estas reflexōessobre a teoria do conhecimento dentro do contexto de uma segunda questāo, a questẫo acerca da funçāo da teologia para a teoria da história de Walter Benjamin.

Gostaria de resumir este contexto teológico das minhas reflexōes em três teses. E, para isso, quero partir de um conceito cunhado por Adorno, que assumi, a saber, o conceito da teologia inversa. Defenderei, portanto, a tese de que Benjamin desenvolve uma teologia inversa. Isso quer dizer que ele procura fundamentalmente um incógnito profano para os motivos teológi$\cos$. E a essa teologia inversa corresponde de forma absolutamente exata uma atitude de comunismo pragmático, como ele mesmo a denominou. Pensem na primeira tese sobre o conceito de história. Eu diria, portanto, que é necessário pensar em conjunto o comunismo pragmático como atitude exigida pelotempoe odesenvolvimentode motivos tcológicos num incógnito profano, mundano - e a imagem do anão na máquina de xadrez tenta explicitar este ponto. O que direi a seguir, sob o lítulo de teologia inversa, refere-se a este complexo todo.

Espero que os senhores possam aceitar, por enquanto, uma definiçāo minha, breve, doque é a teologia inversa: teologia inversa é uma teologia que aplica a si própria a proibiçāo judaica de se fazerem imagens de Deus. A minha primeira tese a este respeito diz: pelo fato de a teocracia, o domínio, o governo de Deus, nāo ter nenhum sentido pohítico, a política mundial do teólogoinversodeve proceder niilisticamente. Isso quer dizer que uma tal política só pode se referir ao registro da felicidade - uma felicidade puramente mundana, profana - $\mathrm{e}$ à caducidade, caducidade do mundo, caducidade da natureza. Omotivopeloqual estou tecendo estas elucubraçōes prévias um tanto quanto complicadas é o seguinte. Quero deixar claro que o tabu enunciado por Benjamin, o tabu sobre os conceitos teológicos na historiografia, que ele enuncia quando diz que nāo devemos utilizar conceitos teológicos aoescrevermos a história, este tabu nẩo deve levar, de jeito nenhum, a um conceito a-tcológico da história. Também isto é, se os senhores assim quiserem, uma definiçāo de teologia inversa. O tabu dos conccitos teológicos na historiografia nãodeve levar ao mal-entendido de termos de desenvolver um conceito a-teológico da história.

Em base a esta reflexẫo, é perfeitamente plausivel que Benjamin conceba a teologia como ciência básica de sua obra mais famosa, a obra sobre as galerias. Portanto, a teologia, enquanto tcologia inversa, é a ciência básica, a ciência fundamental de todo o trabalho histórico de Benjamin. Mencionarei ainda, apenas enquanto tese, o conceito-chave de Benjamin no campo metodológico: a apocatástase histórica. Este nãoé um conceitodogmático, mas metódico, porque se refere a uma técnica de processamento de matcrial, a saber, a técnica que opera com contrastes dialéticos. Benjamin dá um exemplodisso, que talvez também possa parecer plausível aos senhores. Os senhores são um público culto. Talvez não seja assim no Brasil, mas na Alemanha a situação de um público cultoé tal que ele pode chegar a accitar o cinema, mas odeia a televisấo, por se tratar de um meio de comunicaçăo de massas. Conseqüentemente, esse público vê a adaptaçāo de uma grande obra da literatura para o cinema ou para a televisão como o maior dos pecados mortais. Benjamin pega isso como exemplo para deixar claro o que ele entende quando fala $\mathrm{cm}$ apocatástase histórica, e diz que é bobagem, que é uma besteira total dizer que uma adaptaçāo cinematográfica é ruim ou errada de per se. $\mathrm{O}$ que deveria ser feito, seria diferenciar entre adaptaçōes boas e más. Ou scja, aquilo que aparentemente é negativo de per se, a adaptação cinematográfica de um grande texto, deveria ser dividido, através de uma técnica de contrastes técnico-dialéticos, em boase más adaptaçōes. Transferindo-se este método, enquanto princípio, para todos os materiais da cultura, teremos este método da apocatástase histórica. Ou seja, que não existe nada que seja negativo de per se. Tudo o que se apresenta como aparentemente negativo é submetido a esta técnica dos contrastes dialéticos, até que, no fim, tudo fica positivo. Até termos, no fim, uma pletora de positividade comprimida. Esta pletora de positividade, dentro da qual, se os senhores quiserem, nảo há mais nada de mau, nada de negativo, é, de fato, idêntica 
ao antigo programa gnóstico da apocatástase, isto é, a assim chamada restauração final de todos os seres, ou seja, a salvaçâo de tudo da ameaça do mal. Digo isso para o caso de os senhores alguma vez se defrontarem com esse conceito, usado metodologicamente por Benjamin. Como, a partir desta perspectiva, não existe nada de negativo, fica bastante claro que o procedimento crítico, no sentido de uma crítica polêmica, recusante, desvalorizadora, nāo tem mais nenhum sentido para Benjamin. Por isso, para Benjamin, todas, em princípio todas as prognoses críticas, săo carentes de sentido.

A minha segunda tese é um tanto quanto intrincada. Mais exatamente, trata-se de uma enumeração de elementos que se referem uns aos outros. Com cla, cu tento pôr diferentes conceitos-chave de Benjamin dentro de um contexto sistemático, dentro do contexto de uma única formulaçâo, que diz assim. Doutrina é crítica ab-rogada, crítica é teologia inversa, c religiāo é a totalidade concreta da experiência. Se os senhores tiverem diante de si este contexto, dentro do qual a doutrina é crítica ab-rogada; a crítica, teologia inversa $\mathbf{c}$ a religiâo, a totalidade concreta da experiência, fica claro que Benjamin precisa fundamentar o scu conceito de história na imagem da salvaçâo. Fica claro, pressupondo-se que, ao falarmos de religiảo neste contexto, falamos seja numa religiảojudia, seja numa religiāo gnóstica, como ainda terei oportunidade de afirmar.

A minha terceira tese significa um passo para fora desta moldura teológica, que alguns dentre os senhores poderá considerar como molesta, um primeiro passo na direção de uma concretude da teoria da história. Esta terceira tese diz que as categorias político-teológicas cristalizam o mero acontecimento em história. Ou seja, que tudo aquilo que meramente acontece não é história, que apenas as categorias político-teológicas cristalizam aquilo que nós chamamos, na nossa fala cotidiana, de história, cristalizam o mero acontecimento e fazem dele aquilo que Benjamin chama de história. Agora será fácil os senhores compreenderem que, de fato, este conceito de história não é possivel se abrirmos mão da teologia. Eque a tarefa da teologia neste contexto pode ser definida mais precisamente como a restauração da Revelação perdida. Este é um teologúmeno que pode ser encontrado $\mathrm{m}$ Franz Rosenzweig, eque
Benjamin, ao que tudo indica, assumiu. Ele parte da idéia de que os homens perderam a oportunidade oferecida pela Revelaçāo, e que a tarefa da teologia é a restauração da Revelaçăo perdida. Isto seria, naturalmente, um dogma, ou seria, se assim quiserem, teologia pura. É claroque Benjamin náo faz uma coisa dessas. Oque ele fazé justamente precisar esta tarefa da teologia como tarefa do materialismo histórico. Ele cumpre justamente com esta tarefa da teologia, no incógnito do materialismo histórico. Porque a restauraçāo da Revelação perdida significa, dentro desta máquina do materialismo histórico, a cristalizaçâo de fenômenos históricos primordiais. Este conceito de "fenômeno primordial" é um pouco difícil e certamente nos poderá ser explicado por JeanneMarie. É um conceito relacionado com as origens, utilizado por Goethe no contexto dos fenômenos da natureza, como conceito de fenômeno primitivo, e transferido por Benjamin aos contextos históricos. Ali surge entāo o conceito do fenômeno primordial ou da origem histórica.
BENJAMIN POR JULA RAOT-COHN EM FOTO DE SASHA STONE

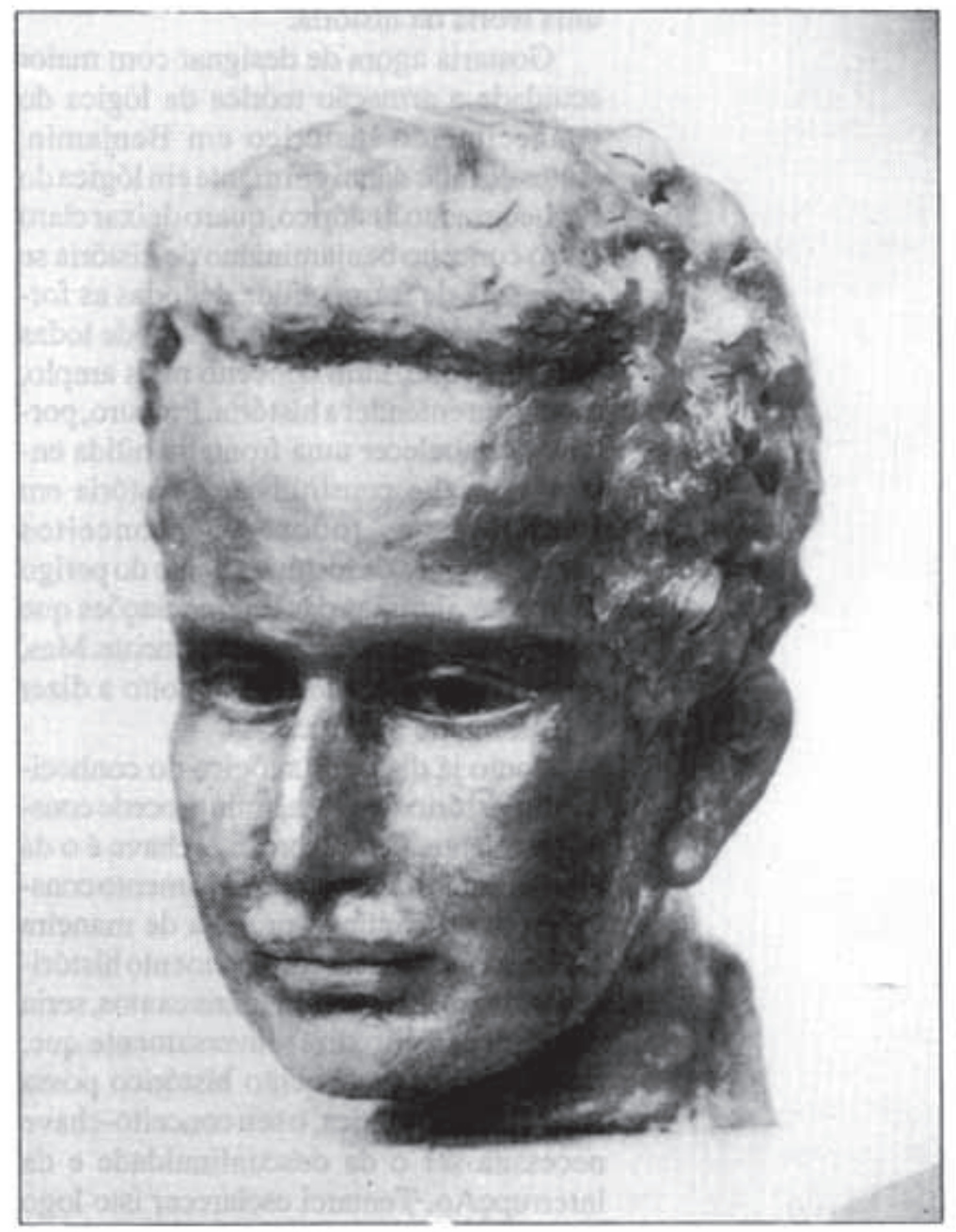


Uma última observaçāoa respeito desta moldura teológica. O termo que surge aqui com freqüência, Eingedenken, nada tem a ver com lembrança ou memória ou recordaçAo no uso corriqueiro destes termos. Eingedenken é um lembrar contra. É interessante o fato de Michel Foucault ter desenvolvido um conceito bastante análogo, o de contre-mémoire, provavelmente sem ter conhecimento da teoria de Benjamin. Existe, portanto, algo assim comouma contra-memória, um lembrar-se contra, e esta contra-memória torna possível algoque é, para nós, o que há de mais surpreendente na teoria da história de Benjamin, a saber, concebermos o passado como algo inacabado, algo que nāo está fechado.

Portanto, se a memória vai ao arrepio da história, o passado ainda nāo está encerrado. Fica em aberto e pode ser usado, portanto, como ponto de referência da utopia. Esta é a reviravolta fundamental para Benjamin, e eu acho que uma pessoa normal não a entende sem mais nem menos. Mais tarde, teremos de refletir mais aprofundadamente sobre o que istopoderia significar concretamente como moldura de uma teoria da história.

Gostaria agora de designar com maior acuidade a armação teórica da lógica do conhecimento histórico em Benjamin. Antes de falar daqui em diante em lógica do conhecimento histórico, quero deixar claro que o conceito benjaminiano de história se diferencia de forma nítida de todas as formas hermenêuticas, historicistas, de todas as formas que, num conceito mais amplo, procuram entender a história. Procuro, portanto, estabelecer uma fronteira nítida entre o conceito construtivo de história em Benjamin e todos os conceitos hermenêuticos de história, ciente do perigo de apagar algumas das diferenciaçōes que oSr.Garber apresentou anteriormente. Mas, for the sake of argument, eu volto a dizer isto assim, de forma crassa.

Como já disse, esta lógica do conhecimentohistóricoem Benjamin procede construtivamente. O seu conceito-chave é o da descontinuidade, e este procedimentoconstrutivo e descontínuo procura de maneira radical referir todo o conhecimento históricoà política.Para sermos mais exatos, seria talvez necessário dizer inversamente que, para que o conhecimento histórico possa ser referido à política, o seu conceito-chave necessita ser o da descontinuidade e da interrupçAo. Tentarei esclarecer isto logo mais a propósito de um dos próximos conceitos-chave, a saber, o do sonho e da imagem onírica da história.

Comecemos com este motivo da imagem onírica da história, que torna possível perceber como o momento da descontinuidade torna possivel referir o conhecimento histórico à política. A metáfora-chave - e até seria possível dizer, se nos digladiarmos criticamente com Benjamin, a metáfora absoluta de Benjamin para o seu conceito de história é a da relaçẩo entre o sonho e o despertar. Benjamin concebe a si próprio como intérprete político dos sonhos da história. Eu até diria que o que ele tenta é repetir a tarefa da psicanálise como lógica do conhecimento histórico. Benjamin tenta, portanto, repetir no registro do conhecimento histórico aquilo que Freud fez com a psicanálise, dentro dos limites da psicologia individual. A partir disto, seria possível deduzir uma definiçAo daquilo que Benjamin entende por modernidade. Antes de chegarmos a definiçEes espetaculares como "a modernidade é o inferno", vamos proceder com mais cautela $e$ dizer que, diante do pano-de-fundo desta metáfora absoluta do sonho e do despertar, modernidade é para Benjamin nada mais nem nada menos do que a forma onírica do tempo, a saber, uma forma onírica que é cega perante a história. Daí a necessidade de interpretar este sonho e do investimento de conhecimento histórico. Como a modernidade nada mais é do que a forma onírica cega do tempo, este sonho precisa ser interpretado pelo historiador. Interpretar um sonho significa, para Benjamin, iluminar historicamente este sonho. Enāoé o caso de que este sonho, que é chamado de modernidade, necessite do historiador para chegar ao seu despertar. Ao contrário, e istoé quase mais interessante e importante, o historiador é quem necessita do sonho, pois só o sonho tem ainda a energia para penetrar no passado, para transpassá-lo. Porque para Benjamin nāoé, de modo algum, o caso de se dizer que o passadoseria um livro abertodentrodoqual poderíamos passear e entender ou nāo entender alguma coisa. Ao contrário, o passado está fechado, e a imensa energia de que necessitamos para irromper neste passado fechado nos é dada apenas no sonho. Portanto, apenas o sonho tem a força de abrir o passado e de nele irromper. O sonho depende do historiador e o historiador depende do sonho. Isto é extremamente importante.

Pois é, uma época está deitada e sonha 


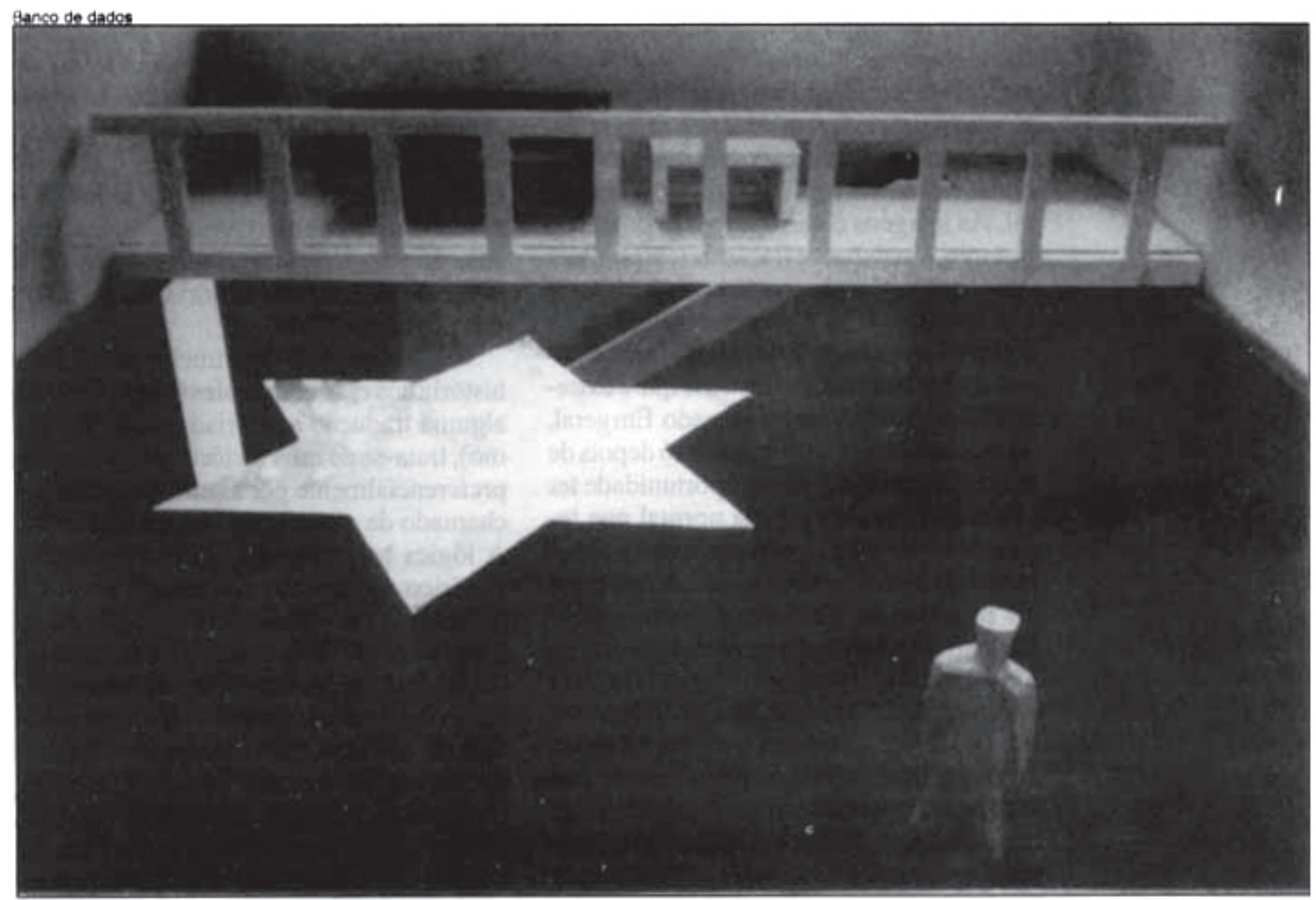

adormecida. Lembrem-se da famosa frase de Goya, que disse de forma muito análoga que o sonho da razão engendra monstros. Trocando em miúdos, isso quer dizer que o sonho da razāo esclarecida, da razAo iluminista, engendra monstros. Quer dizer, simplesmente, que estaépocadolluminismo é um sono, um sono profundo. Esta é uma posiçāo compartilhada, creio eu, por Benjamin. Portanto, se uma época jaz num sono povoado de sonhos e engendra monstros, é necessário, se se quiser salvar esta história, egressar da história, sair da mera contemplaçAo histórica; é necessário dar à política a primazia diante da história.

Também nâo dá para se entender esta idéia sem mais nem menos, a idéia de que, por amor à história, é necessário dar primazia à política diante da história. Dentro do nosso contexto de teoria do conhecimento, isto significa que é necessário interromper politicamente o sonho da história para tornar legível este sonhoda história, para tornálo decifrável de algum modo. Para Benjamin, isto significa sempre tornar possível que este sonho da história possa ser referido ao presente. Ou seja, é o nosso problema da atualidade. Para que a história possa se atualizar, ela precisa ser interrompida, o sonho precisa ser interrompido, a história precisa ser referida politicamente ao presente. Só assim ela se torna legível $\mathbf{c}$ atual para nós. E a época que, para Benjamin, jaz neste sono povoado de sonhos não é mais a do lluminismo, mas é a do capitalismo. E, na minha opiniāo, umas das muitas definiçổes fáceis da modernidade que correspondem a Benjamin, ao lado daquela de que a modernidade é o inferno, é naturalmente aquela de que a modernidade é o capitalismo.

Mais um ponto no campo da teoria do conhecimento contra o historicismo. Esta modernidade, isto é, o capitalismo deitado num sono povoado de sonhos, tem uma característica que é constrangedora, sobretudo para os historiadores, a saber, a de que nāo é possível contar histórias da modernidade. A modernidade foge da forma épica. Não dá para contar nada de instrutivo a respeito da modernidade. Por isto diz Benjamin: "A história se decompóe em imagens, nāo em histórias”. É exatamente isso o que isto significa. Nảo há mais histórias que possam ser contadas a respeito da modernidade. A forma épica está gasta, nåo é mais capaz de produzir qualquer estímulo. Porque a história, justamente, não pode
ESBOÇO CÉNICO PARA A EXPOSIÇAO DE HOMENAGEM HOMEM PEQUENO CORCUNDAE ANJO DA HISTORIA. BENJAMIN, TEORICO DA MODERNIDADE" 
mais ser decomposta em histórias, mas em imagens, com o que teríamos chegado exatamente à teoria de Benjamin da imagem histórica e da imagem dialética da história. $\mathrm{O}$ que torna problemáticas estas imagens dialéticas da história é o seu status temporal. As imagens da história estão presas ao instante, à mais breve fração de tempo. Quer dizer que estäo presentes apenas durante um instante. Nảo é possível folheá-las e admirá-las contemplativamente, mas é necessário colhê-las num instante que é extremamentedifícildeserprolongado.Emgeral, a gente reconhece este instante só depois de ele ter passado, depois da oportunidade ter se perdido. A experiência normal que temos da história é a de que perdemos a oportunidade de colher a imagem histórica que ela nos oferece. Também neste momento fica extremamente claro por que a teoria da história de Benjamin tem de ser construtivista. Tem de ser construtivista para ter o poder de apanhar a imagem histórica no mais breve intervalo de tempo de que dispomos, instantaneamente, no estalar de um relâmpago. Aliás, a metáfora do relâmpago é outra das metáforas preferidas por Benjamin.

Em alemão, o conceito de história é claramente ambiguo. Por um lado, história é aquilo que acontece, que sucede, que ocorre, os atos momentosos, os atos de Estado. Por outro lado, história é aquilo que se escreve a respeito daqueloutro, por exemplo, a gente escreve a história do século XVIII ou XIX. Esta ambigüidade é, em geral, um empecilho para o conhecimento, mas Benjamin procura aguçá-la dialeticamente, aguçá-la para ela se tornar um conceito epistemológico próprio. A famosa $12^{a}$ tese sobre o conceito de história diz, mostrando claramente este aguçamento dialético da ambigüidade do conceito de história: " $\mathrm{O}$ sujeito do conhecimento histórico é a própria classe dominada e em luta". Isto nāo é evidente de per se, na medida em que pareceria mais fácil pensar que a classe dominada luta $\mathrm{e}$ faz história, $\mathrm{e}$ os historiadores escrevem a história e sãoos sujeitos do conhecimento da história. Mas justamente isso é que nãoé o caso. Benjamin afirma algo que é extremamente rico em implicaçōes, afirma que a classe dominada, a classe que luta é que é o sujeito do conhecimento histórico. Isso quer dizer, portanto, que o conhecimento da história é para Benjamin fundamentalmente inseparável da política revolucionária.
Vou ainda levantar outros três pontos. Um deles é aquilo que eu, juntando-me ao historiador da arte, Alois Riegel, chamaria de história dos casos limítrofes. O segundo será a concepção da imagem dialética. Quanto ao terceiro e final, ele se refere à minha opiniāo de que o cinema apresenta a solução para todos os problemas que Benjamin tinha diante da história, do ponto de vista epistemológico.

A respeito do primeiro ponto, o da história dos casos limítrofes (e nem sei se há alguma traduçâo apropriada para este termo), trata-se de uma história que se orienta preferencialmente por aquilo que pode ser chamado de casos extremos ou limítrofes. A lógica benjaminiana do conhecimento histórico acompanha em muitos pontos o pensamento do historiador da arte, Alois Riegel. Esta história dos casos extremos ou limítrofes conjuga o conceito da necessidade não ao decurso da história, mas aos extremos. Ou seja, que a única coisa que é decisiva e interessante são os extremos. Quem se tiver dado ao trabalho de observar o livro de Benjamin sobre o drama barroco alemão terá notado que nele só são procurados casos extremos a fim de serem objeto de interpretaçäo. Enisso há apenas uma coisa que é decisiva, a saber, que o passado, enquanto objeto histórico legítimo, enquanto objeto histórico stricto sensu, precisa ser extraído do seu caráter de passado e levado para uma concretude superior, que Benjamin chama de Jetztsein, ser-agora. Este conceito, para consolo de todos os presentes, não é mais fácil de entender para alemães do que para quaisquer outros. Vou tentar esclarecê-lo. Benjamin tem a idéia de que oque passou tem menos concretude no passadodoque na concretude de que é objeto através de nossa atualização. Quando presentificamos algo passado numa rápida imagem, como Benjamin também gosta de dizer, esta rápida imagem ganha uma concretude mais intensa do passado do que o passado teve na facticidade da história. Estou tentando explicar esta questão porque ela é, por um lado, difícil de entender e, pelo outro, extremamente importante para a teoria de Benjamin. Ele elabora o conceito de que o passado adquire um grau de concretude maior do que o que originalmente apresentava mediante a atualizaçāo, mediante uma atualizaçāo bem-sucedida. Eu diria que só há um caminho possível para entender este conceito, a saber, o da comparação com a psicanálise. Freud havia 
feito uma descoberta igualmente fantástica uns vinte anos antes, a de que existe uma relação inversa entre o acontecimento vivido na realidade e a lenbbrança. $E$ reconheceu esta relação inversa entre o acontecimento vivido na realidade e a lembrança comosendoa pré-condiçāopsicológica para o assim chamado recalque. O que significa isto? O exemplo mais fácil para entender esta questAo é o assim chamado trauma. Um trauma tem um efeito posterior semelhante aode uma experiência imediata, mas no nível inconsciente. Isto quer dizer que Freud mostrou que as experiências traumáticas de um ser humano ocorrem num tempo $\mathrm{cm}$ que nāo têm ainda a funçāo de choque que só adquirem posteriormente. O ser humano é submetido a determinados traumas também nas fases infantis, traumas que não produzem choques nessas fases, mas apenas mais tarde, em outras fases da vida, $\mathrm{em}$ que os traumas exercem toda sua força de choque. É exatamente a isso que Benjamin se refere quando diz que a posteriori, na nossa atualizaçāo, as imagens históricas ganham uma concretude maior do que no tempo em que os acontecimentos realmente ocorreram. Abreviando, poder-se-ia dizerque omodelofreudianoda* ulterioridade é o modelo benjaminiano da concretude. histórica. Ou, em outras palavras, a atualidade do acontecimento fixado na contramemória é maior do que a atualidade do acontecimentoem seu temporeal. Achoque mesmo com as mais geniais artes de traduçîo, tudo isso continuará a ficar pouco claro, mas eu farei tudo o que for possível para esclarecê-lo durante o debate.

Depois disto passo rapidamente à imagem dialética e ao cinema. Na lógica do conhecimento histórico, a imagem dialética passa a ocupar o lugar da idéia. Benjamin tinha se proposto a produzir nem mais nem menos do que uma ideologia materialista, que consistiria em toda uma série de imagens dialéticas, em uma série inumerável de imagens dialéticas. Eele nāo queria produzir essa ideologia materialista para documentar oseu platonismo, oseu partidarismo por Platão, nem para tornar mais compreensível o filósofo, mas tinha o motivo sistemático de fazer uma ponte por sobre o abismo que separa o conhecimento da verdade. Benjamin queria, pois, fazer uma ponte por sobre este abismo tinha o projeto concreto de fazê-la através de uma ideologia materialista de imagens dialéticas. $\mathrm{O}$ fato de o conhecimento histórico ser passível de ver- dade, o fato de que conhecimento e verdade tenham algo a ver um com o outro, este fato sempre foi posto em dúvida no mundo esclarecido, no mundo posterior ao Iluminismo, a partir de Kant. Qualquer homem esclarecido mantém esses dois mundos separados. Mas o que torna o conhecimento históricocapazde verdade, para Benjamin, nada mais é do que justamente o perigo da história e a volatilidade, a inconstância de suas imagens, a respeito da qual o Sr. Garber já chamou a atençăo. É justamente o momento do perigo, ao qual está amarradoo conhecimentodas imagens dialéticas, o que torna este conhecimento passivel de verdade. Eperigosignifica, aqui, a possibilidade de perda dessas imagens. Durante o debate anterior, eu já havia chamado a atenção para o fato de este ser o lugar em que Benjamin desenvolve a sua teoria da Geistesgegenwart, termo este que poderia ser traduzido como presença de espírito, ou presença de consciência.

Um derradeiro ponto. $\mathrm{O}$ que significa concretude para Benjamin? O que significa, trocando em miúdos historiográficos e longe da teoria do conhecimento? A concretude é para Benjamin o critério mais importante em suas construçōes históricas. Este é um ponto que, sem lugar a qualquer dúvida, o pōe em contato com a Escola de Frankfurt. Depois de falarmos tanto naquilo que o diferencia de Adorno, temos aqui um motivo comum. A concretude é o mais importante critério das construçōes históricas. E, por isso, o meio para o conhecimento histórico nāo é a história oficial, a história dos grandes atos de Estado. Justamente as grandes datas - 1789 e outras semelhantes - não sāo, justamente, o meio para se obter o conhecimento histórico. Benjamin procura, pelo contrário, ler a imagem da história a partir de seus traços mais modestos, montá-la a partir de seus detritos. Existe uma frase famosa dos Goncourt, "fazer história do lixo da história". É exatamente isso que Benjamin faz, ele constrói história a partir do lixo da história. E, para isso, ele usa novamente uma técnica de Freud, a saber, a de decifrar banalidades, coisas aparentemente indiferentes, como imagensque encobrem mensagens inconscientes. Ora, esse mundo da banalidade, esse mundo dos detritos da história, ganhou um grande e poderoso agente, contemporâneo de Benjamin: o cinema. A análise das coisas, feita por Benjamin, essa análise detalhista das coisas, ganhou um poderoso motor: o cine- 
ma mudo. Por isso Benjamin pôde afirmar que o cinema mudo havia ampliado infinitamente a capacidade de percepção do ho$\mathrm{mem}, \mathrm{e}$ que havia conquistado um mundo novo, o mundo do inconsciente ótico. Esta ć uma formulação análoga à do inconsciente psicológico. O inconsciente ótico seria o espaço do mundo que nós não pudemos perceber ainda devido às limitaçōes de nossa ótica natural, dos nossos olhos. É muito importante assinalar que se trata de uma ótica antifísica, ou seja, que todas as suas descobertas importantes são feitas nela ao arrepio da natureza. Esta ótica antifísica do cinema não apenas nos mostra o que os nossos olhos físicos vê $\mathrm{em}$, não apenas o faz melhor, de maneira mais clara e nítida e maior, mas essa ótica antifísica conquista um espectro inteiramente novo da percepçáo sensorial e abre uma formaçāo estrutural inteiramente nova da matéria. Benjamin diz: "Com o cinema surge realmente uma nova regiảo da consciência". Ou seja, uma regiảo nunca dantes descoberta da consciência.

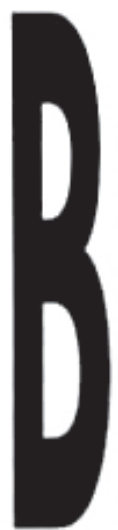

\section{LEANDRO KONDER}

om, cu gostaria de começar por esta pergunta que foi dirigida a nós e à qual o professor Bolz já encaminhou uma resposta e pra qual eu propriamente não tenho uma resposta.

A pergunta é: É preciso teologia para pensar ofim da História? E essa pergunta teoricamente está dirigida a Walter Benjamin e quem responde é Leandro Konder, entảo Leandro Konder tem alguma dificuldade de imaginar como Walter Benjamin responderia a essa pergunta.

Na macumba tem um personagem que recebe o santo, que é o "cavalo", e eu desconfio que eu seria sempre um mau "cavalo" pro espírito de Walter Benjamin. Não acredito que ele possa baixar em mim aqui e falar pela minha voz, entāo vou expressar as minhas perplexidades.

Acho, num primeiro contato com a questâo, que o Benjamin nāo teria dúvida cm responder: a tcologia é necessária. Eu preciso dela. Isso fica muito claro na obra dele, fica muitoclaro na elaboraçāodopensamento dele, na reflexăo que ele desenvolve. A dúvida que me ocorre é relativa à segunda parte da frase que encerra a pergunta, a parte que se refere ao fim da história. Tenho dúvida porque acho que existe uma possível interpretação do fim da história no pensamento de Benjamin. Pensando a redençåo como fim da história, de alguma forma Benjamin associa, dentro da tradiçāo judaica, a redençăo com a chegada do Messias. A chegada do Messias é o fim da história. Aomesmotempoa redenção, que pode ser vista como fim da história,é identificada com a revolução. E aí as coisas se complicam porque a revoluçáo também pode ser pensada como a fundaçâo de uma nova história, sobretudo a revolução benjaminiana. Benjamin tem um conceito especial de revolução: é a ruptura com uma história que se cristalizou, que se mecanizou, uma história que se atrelou a um certo trilho, que enveredou por um caminho que resulta no sempre igual, ou entảo que corre vertiginosamente e sem intervenção de sujeitos humanos na direção do abismo, uma história na qual a realização dos homens se torna desrealizaçāo.

Eessa história nảo só se impöe a alguns teóricos, claramente conservadores, como ela é, de alguma forma, assumida de maneira insuficientemente crítica por vários teóricos de esquerda. Entāo Benjamin enfrenta o desafio de polemizar com esses teóricos conservadores c também com o pensamento de esquerda que endossa essa visão da história.

Há várias matrizes para essa concepção da história, para csse modo de pensar a história; um representante clássico da maior competência c da maior seriedade desse pensamento seria Leopold von Ranke, o famoso historiador alemão do séculopassado, que dizia que era preciso reconstituir as coisas, reconstituir os fatos exatamente como eles aconteceram. E Benjamin assinala claramente a limitação dessa concepção da história. Se isso fosse possível (de certa forma é impossivel a gente reconstituir os fatos disponíveis, postos ao nosso alcance), mas se fosse possivel, nós teríamos o quê? Nós teriamos uma versăo da história. Aversāoque está passando por aqueles fatos. Aí nảo teriamos as vivências, as experiências subjetivas dos homens que viveram aquelas situaçöes pelas quais a história passou, os anseios, os deseperos, as dores, os sofrimentos, os sonhos, as fantasias, sobretudo dos oprimidos.

Entāo Benjamin reage contra isso. Ele se empenha em escapar da tirania desta hisUniversidade Católica do Rio de Janeito. 


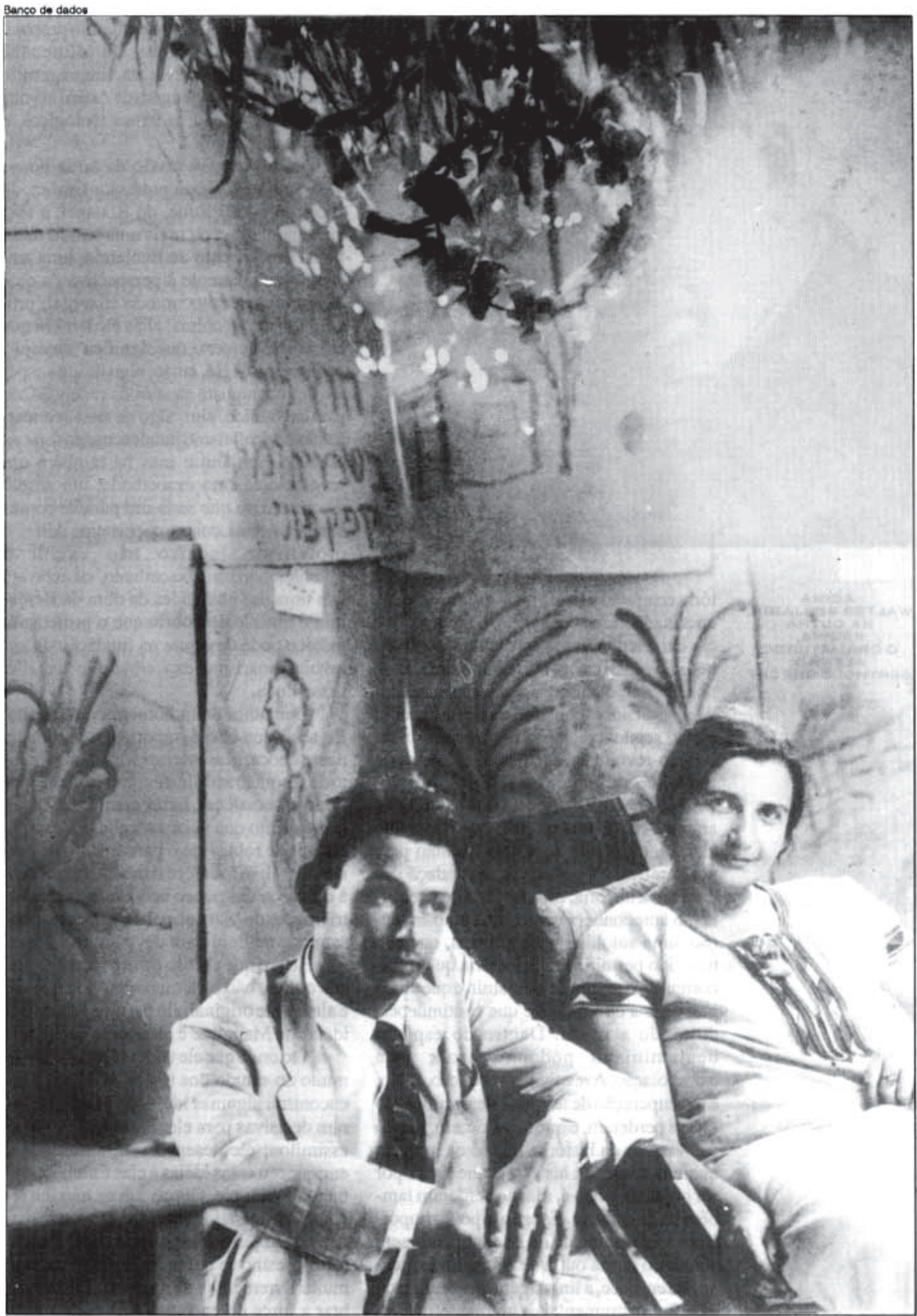

O CASAL 8CHOLEM EM JERUSALEM, 1026 


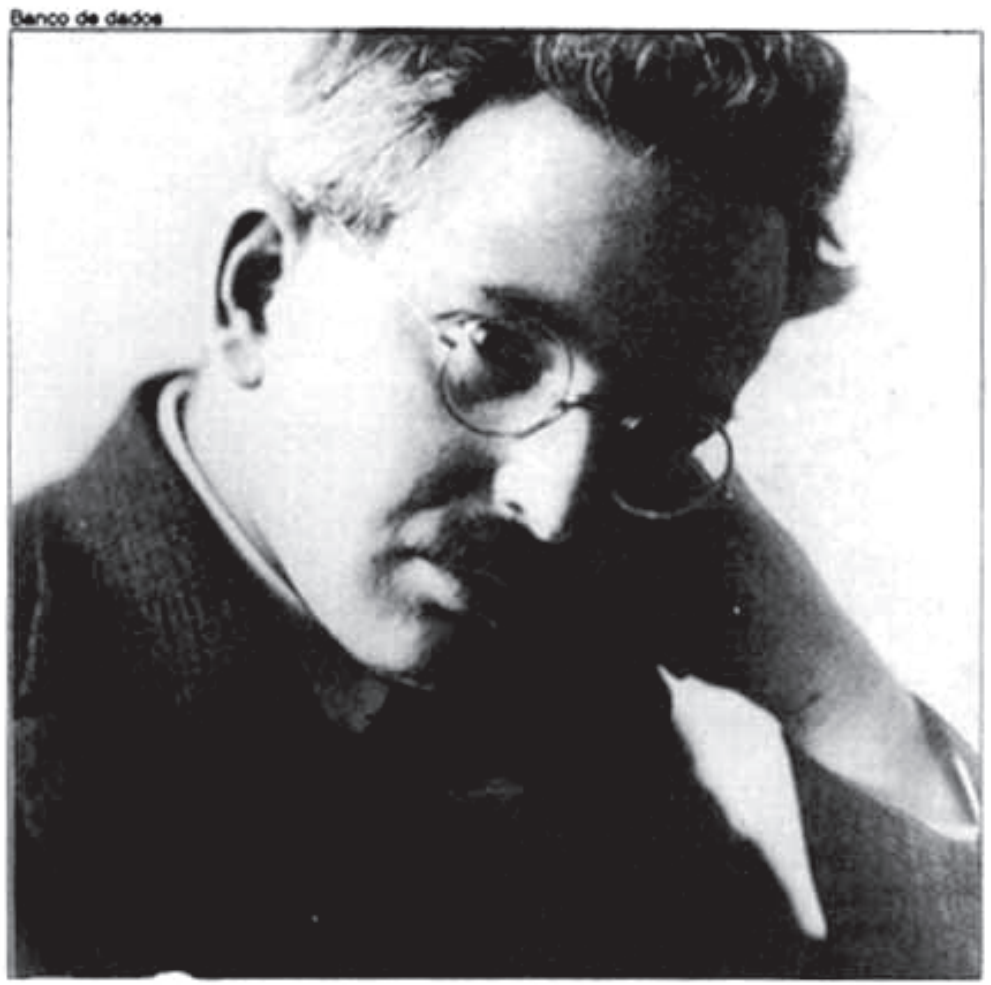

WALTER BENJAMIN. NA OUTAA PAGINA

O DAAMATUARO ALEMAO BERTHOLD BAECHT tória coagulada, dessa história corrompida, encaixada numa concepção de tempo, que ele caracteriza como um tempo homogêneo. E pra isso, para enfrentar o desafio de nos libertar, de libertar o nosso pensamento, libertar nossa consciência dessa história, é que, segundo ele, nós precisamos da redençăo-revolução; a redençẫo é revoluçâo. Entấo, o que seria essa redençāo-revolução? Ela seria de alguma forma, também, ao meu ver (ć uma questāo que não tenho clareza, cu ponho aqui uma questão para nossa reflexảo), poderia ser a fundação de uma nova história, uma história que permite um autoconhecimento, uma auto-invenção, uma autolibertação humana, que não tem sido permitida pela história que transcorreu até o tempo de Benjamin e que ainda percorria a época dele c que continua percorrendo a nossa. Dentro do espírito benjaminiano podemos fazer esta extrapolaçăo. A revoluçāo-redençāo, entảo, é a recuperação de tesouros de significaçāo que se perderam, c que se perderam, não só nas versōes da história, nâo só na imagem que nós temos da história c que passa por ser objetiva, $\mathrm{c}$ nảo , mas se perderam também na linguagem. Esse é um ponto importante no pensamento de Benjamin que será abordado numa outra sessão, a linguagem que se enrijece, a linguagem que é utilizada para fins instrumentais, puramente, ou predominantemente, ou quase que exclusiva- mente comunicativos; $\mathrm{e}$ Benjamin preconiza uma revitalização da dimensão nomeadora, inventiva, da linguagem; a criatividade da linguagem de Adảo(aívolta a tcologia, voltam os temas teológicos, o período adâmico).

Acho que na sessão da tarde houve várias referências do professor Garber, do professor Willi Bolle, do Rouanct, a essa ambigüidade: seria mais uma tensão interna do pensamento de Benjamin, uma tensăo interna inerente à perspectiva da qual Benjamin está procurando enxergar, procurando ver as coisas; aliás ele lembra que teoria vem de teoro, que significa "cu vejo", "cu enxergo". Há, cntão, algo de uma espécie de reconquista através da redençăo, do paraíso biblico, sim, algo de uma reencarnaçãodoprofetismojudaico, muito forte na obra do Benjamin; mas há também um revolucionarismo exacerbado, um anseio de criação do que seria um paraíso comu. nista. As duas coisas cocxistem. Aliás, o profetismo judaico nảo exclui o revolucionarismo exacerbado, cu acho até que uma das novidades da obra de Benjamin é que ele descobriu que o profetismo judaico pode desaguar na fundação de um revolucionarismo exacerbado, c trabalha nessa linha.

Benjamin é um homem de esquerda. Eu acho que isso é importante, porque na nossa época, nesses tempos de desabamento dos esquemas doleste europeu, das experiências socialistas, há uma certa tendência, que eu sinto que vai crescendo, na medida $\mathrm{em}$ que se robustece o pensamento de tipo neoliberal, se fortalece também a tendência a descartar um pouco cedo demais as contribuiçōes de Marx ao pensamento, e o pensamento de Benjamin deve muito a Marx.

Éclaro que ele nãoé um marxista igual aos outros, não há a menor dúvida que ele éaltamente original, cle faz uma leitura das idéias de Marx que é altamente peculiar.

Nãocreio que ele tenha se aprofundado muito no estudo dos textos de Marx. Mas encontrou algumas idéias de Marx que foram decisivas para ele. Essas idéias, ele as assimilou; ele desenvolveu, aprofundou, enriqueceu essas idéias e elas foram fundamentais para ele. Outras talvez nåo lhe tenham interessado tanto. De qualquer maneira, a relaçấo dele com omarxismoé muito forte, mesmo se tratando de um marxismo muito livremente interpretado. Basta lembrar a força do encontro dele com o livro História e Consciência de Classe, que é um 
livro muito marcante; e nāo podemos esquecer o encontro dele com Asja Lacis, moça comunista por quem cle se apaixonou. Benjamin encontrou no marxismouma confirmaçāo de uma rebeldia que já existia antes. A relaçāo de Benjamin com a socicdade burguesa, a relação de Benjamin com a história que leva a sociedade burguesa, é marcada por um espírito permanentemente, agudamente, implacavelmente crítico.

E o marxismo entra nesse contexto como uma fundamentação teórica eficiente de algumas das intuiçōes que ele tinha desde o começo na sua rebeldia, no seu inconformismo, na sua recusa da cultura burgucsa. Ele aproveita o marxismo c enriquece algumas das suas idéias, aprofundando-as; c isso se nota, por exemplo, nos estudos do século XIX que cle realiza, mostrando no século XIX o solo de onde brotaram algumas das perverçōes mais graves do século XX. O marxismo está presente nas análises que ele faz da sociedade francesa, seguindo as pistas proporcionadas por Baudelaire; no exame de Paris, capital do segundo império, a Paris de Napoleâo III e de Hausmann. Ele também aproveita omarxismo, um poucovia Brecht, como um elemento essencial da análise da relaçäo entre o produto cultural, tanto com as rclaçōes de produçāo como com as forças produtivas, comodesenvolvimentodas forças produtivas. Mas é claro que o marxismo não bastou a ele, ele não parou $\mathrm{cm}$ Marx, nảo tinha sentido para ele parar num autor que, embora rico, era um homem que se inseria num universo que padecia de certas limitaçöes; ele queria alguma coisa que fosse mais longe, mais fundo, um pensamento cujoquadro teórico fosse mais rico do que aquele que Marx, e sobretudo os marxistas, apresentavam a cle. Os marxistas constituem um capítulo bastante significativo na experiência de Benjamin e ele tcm uma relação difícil com os marxistas, porque ele é um marxista original c rebel$\mathrm{de}$, que se insurge constra as doutrinas codificadas (que vinham sendo elaboradas c adotadas $\mathrm{cm}$ nome do marxismo). Os marxistas cram muito sectários. Benjamin conta como ficou mal impressionado com o contato com um crítico soviético falando de Proust; ele tinha uma grande admiração por Proust, era um homem de um bom gosto literário muitogrande, e ficou muito chocado com osectarismo. Daí os problemas que teve com a publicação do verbete sobre Goethe, que escreveu para a enciclopédia

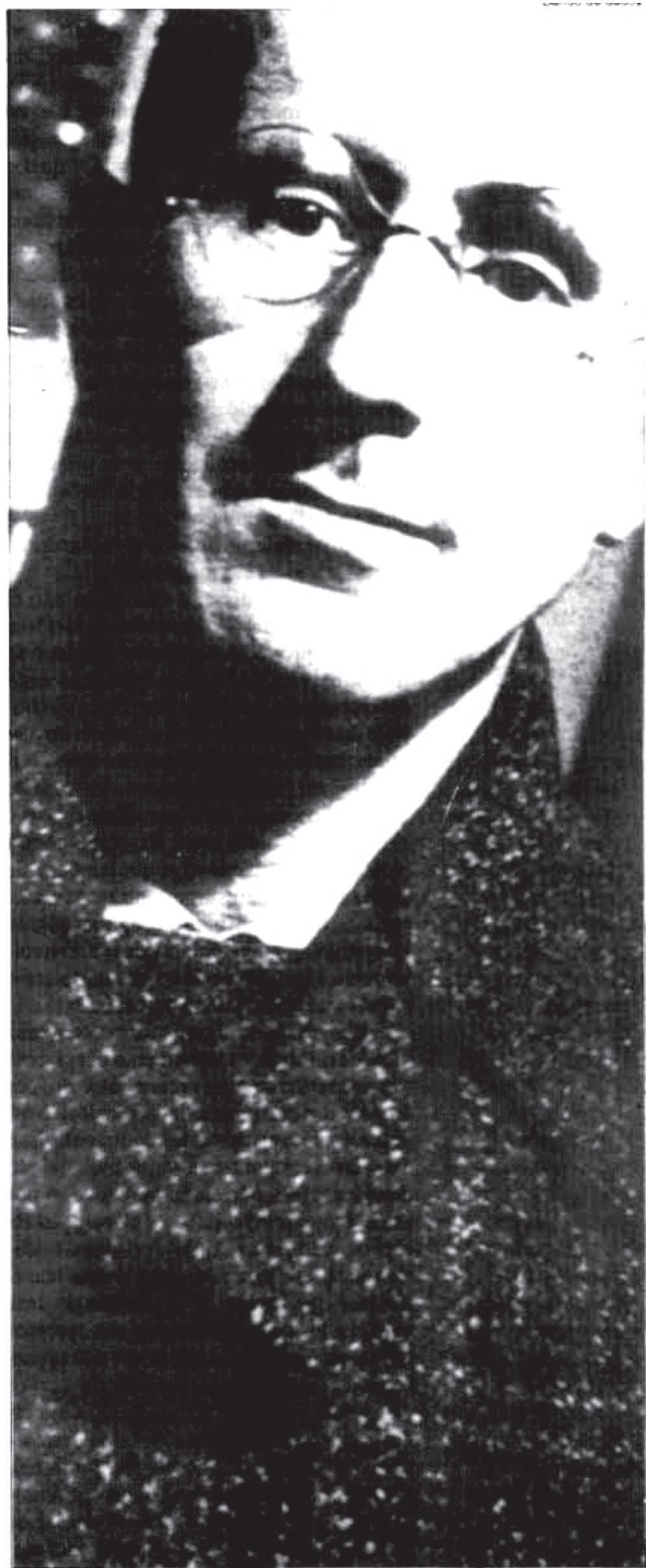


soviética. E havia a convicçāo que ele tinha de que pior do que o sectarismo era o oportunismo dos marxistas, tanto dos marxistas social-democratas, como dos marxistas filiados ao movimento comunista. Ele via de alguma forma na origem desse oportunismo o ponto de vista segundo o qual o marxismo proporcionava a essa gente uma certa doutrina capaz de interpretar a história "tal como ela efetivamente tinha transcorrido"... Um ponto de vista comprometido com a aceitação de uma certa continuidade histórica. Era uma continuidade relida à luz dos critérios indicados por Marx e interpretados pelos marxistas, mas era continuidade e essa continuidade cra inaceitável. Era a idéia de que odesenvolvimento das forças produtivas desencadearia uma crise nas relaçōes de produção $\mathrm{e}$ forçaria a criaçāo de uma sociedade nova.

Isso, para ele, era inteiramente inadmissível; essa idéia era inaceitável.

Entāo, ele disse: a revoluçāo nāo é, necessariamente, a locomotiva da história. Benjamin propöe que ela pode ser o freioda locomotiva, quando a história está desembestada, quando otrem fugiu ao controle do maquinista e está seguindo um caminho insensato; entäo frear esta locomotiva é um ato perfeitamente revolucionário.

Ele é coerente com esse ponto de vista, ele manifesta uma certa afinidade com a idéia de Rosa Luxemburgo que também, de alguma forma, se insurge contra essa visão, embora de forma não tão aguda quanto Benjamin, quando ela diz que o desenvolvimento histórico pode levar tanto para o socialismo como para a barbárie.

Benjamin, de alguma forma, tem essa idéia de que o desenvolvimento por si mesmo nảo tem o destino preestabelecido, por isso ele diz que o materialista histórico insiste em escovar a história a contrapelo. Isso é a política. A política é o aprofundamento da yisảo crítica que ele sempre teve. A política é o caminho para a interrupçăo da continuidade com a qual o processo histórico se apresenta a nós, e que é uma continuidade que resulta da imposiçăo de uma versão a história conveniente aos opressores atuais (que são os herdeiros dos opressores do passado).

Então, o resgate da história dos vencidos, o resgate das aspiraçōes dos derrotados, dos gritos, das dores, dos protestos, das manifestaçōes de inquietaçāo, de rebeldia, esse resgate faz parte da luta pra salvar todas as aspiraçōes libertárias do passado.
É a revoluçâo como apocatástase histórica, que foi mencionada aqui pelo professor Bolz. A apocatástase é aquele conceito do Orígenes que é um pensador cristāo anterior ao período da igreja triunfante, um representante da igreja padecente, que foi morto, mártir da igreja e que tinha a idéia de que a onipotência de Deus não era bem compreendida, nem sequer pelos cristāos, porque Deus tinha tanto poder que ele salvaria primeiro os justos, depois os pecadores e por fim o próprio demônio. O demônio seria, afinal, resgatado, e Benjamin viu nisso uma idéia fecunda, que precisava ser retrabalhada num novo contexto; e trouxe isso para o pensamentodele, para a filosofia da história dele, na forma de uma concepçāo da revolução. E a revolução será uma vingança de todos os medos, de todas as humilhaçōes, de todas as frustraçōes, de todas as dores impostas aos oprimidos do passado. Nesse sentido é que ele precisou da teologia. Ele precisou da teologia porque constatou que a visāo da história trazida, inclusive pelos materialistas históricos, era uma visão que escamoteava o caráter problemático da história que se manifesta nas "imagens dialéticas".

Estou retomando aqui observaçōes do professor Bolz, que acho justas e fecundas. A história só pode ser pensada criticamente através das "imagens dialéticas" porque as "imagens dialéticas" é que nos libertam da camisa de força (isto foi mencionado aqui pelo professor Bolz), scrvia para restaurar a revelação que os homens perderam, que os homens desperdiçaram, que os homens năo souberam aproveitar; mas a tcologia servia também, em Benjamin, para restaurar a revoluçāo que os revolucionários não souberam concretizar, que os revolucionários deixaram que se fanasse, que murchasse. Benjamin busca na teologia elementos que lhe permitirảo pensar a revolução numa nova esfera de irradiaçāo, numa nova escala, numa nova grandeza.

E a interrupçāo do sonho da história através de um despertar, que assume características muito violentas, que só o quadro de referências proporcionado pela teologia podia dar. Por quê? Porque o marxismo estava transformado numa doutrina mais ou menos domesticada, adaptada a critérios científicos bem comportados, e ele queria uma ampliação dos horizontes do pensamento de esquerda. Ele nảo se conformava com a reduçāo do pensamento de esquerda a uma doutrina que se limitava à análise 
pretensamente científica das relaçōes sócio-econômicas e se limitava às urgências da luta político-partidária. Aquele quadro era pobre, nāo engendrava paixōes suficientemente fortes. Tem uma crítica, Susan Buck-Morss, que escreveu sobre Benjamin, e disse que no fundo, a pretextode sensatez, de senso de realidade, de equilibrio, o que os revolucionários marxistas faziam era encaminhar a proposta de uma revoluçāo minguada, de uma revoluçāo que estava sofrendo, diz Susan Buck-Morss, de "impotência sexual".

Então a teologia era chamada a curar essa impotência sexual da revolução, era um antídoto contra..., acho que posso falar essa palavra porque está noAurélio: contra broxura. A revoluçāo precisava ser pensada como uma superação da broxura. Evidentemente, isso soa um tanto pitoresco, mas a idéia tem uma importância muito grande para nós, sobretudo na época atual, sobretudonum periodode embananamento. Agora, novamente, opensamentode esquerda se vê diante de uma grande crise; e aí aparecem sempre pessoas para dizer: essa é a última, essa é a crise final, agora vai acabar, aquela corja vai tomar juízo. Então, é bom lembrar que as experiências das crises passadas geraram grandes reflexōes criativas e radicais.

Benjamin busca referências que são encontradas, através da teologia, aquiloque o professor Bolz mencionou aqui como a busca do incógnito, aquilo que não está ainda conhecido. Isso é muito importante no pensamento dialético, se nós nos instalamos na área do já conhecido, podemos ter certeza de que estamos pensando de uma maneira pobre. O nosso pensamento precisa do ainda nāo conhecido, porque a nossa açāo depende do ainda nāo acontecido. $\mathrm{O}$ nosso projeto tem um compromisso com o novo e o novo não brota automaticamente, mecanicamente, do existente; entäo, a busca do incógnito se insere no âmbito das preocupaçốes políticas mais apaixonadas do Benjamin, como também, em ligação com a busca do incógnito, a busca do infinito, que é um tema essencial dopensamento dialético e que de repente ficou entregue exclusivamente aos teólogos ou então a alguns filósofos idealistas.

O pensamento materialista que se prezava, naépoca de Benjamin, se duvidar ainda hoje, nāo lidava com essa questāo espinhosa do infinito. Eu gosto muito de fazer experiências com meus alunos, puxar o as- sunto do infinito e ver como reagem. Entāo, tem alguns que se entusiasmam, mas freqüentemente são religiosos, e os marxistas ficam muitoperplexos, comoé que você, um marxista, está falando do infinito... Eu digo, isso é fundamental, esse é um ponto de honra de nossa reflexão. Nós temos que pensar, essa dimensão infinita é uma dimensảo essencial da realidade e se nós não encaminhamos uma relaçāo com ela, nós năo vamos conseguir lidar com a criatividade do sujeito humano, com a capacidade do homem de inovar sempre, de se superar a si mesmo. Não há limites previamente estabelecidos para a aventura humana. E os teólogos proporcionavam a Benjamin elementos importantes para ele discutir a dimensāo infinita dessa realidade.

Benjamin encontra tais elementos, por exemplo, em Abrahão Abulafia, que é um comentador da cabala do século XIII, que chama a atenção da relação da linguagem humana com a linguagem de Deus, assegurando que a linguagem adâmica era uma linguagem na qual havia invenção, havia criaçäo. A criatividade de Deus se expressa já no começo do Gênesis, quando se define que "no começo era o Verbo"; quer dizer, a linguagem é um elemento essencial da criatividade de Deus e, por extensăo, da criatividade do homem. Se na linguagem nāo há criatividade, o homem está vivendo uma época muito ruim, está vivendo num mundo muito empobrecido. Opensamento de Benjamin o pōe em contato com a necessidade da grandeza, incita-o à busca do absoluto, que se torna muito problemático para ele, na medida $\mathrm{cm}$ que o autoconhecimento do homem nāo pode ser servido como um prato feito, $\mathrm{em}$ nenhuma doutrina filosófica.

Benjamin pensa essas questōes sempre em ligação, eu volto a dizer, a meu ver, sempre em ligaçāo com preocupaçōes críticas e com o prolongamento natural, o desdobramento inevitável dessas preocupaçōes críticas, que são as preocupaçōes políticas.

Se nós nảo mobilizarmos energias suficientes para realizar mudanças profundas e significativas, não seremos jamais capazes de escapar dessa história $\mathbf{e}$ aí voltamos àquela questâo inicial: escapar dessa história será construir um paraíso sem história, será aportar ao final da história? Ou será fundar uma história nova? Deixo esta questão $\mathrm{em}$ aberto. 